\title{
Research on the Characteristics of Alzheimer's Disease Using EEG
}

\author{
Taishi Ueda Non-member (Tokyo Institute of Technology, tueda@io.mei.titech.ac.jp) \\ Toshimitsu Musha Non-member (Brain Functions Laboratory, Inc., musha@bfl.co.jp) \\ Tohru Yagi Member (Tokyo Institute of Technology, RIKEN, tyagi@mei.titech.ac.jp)
}

Keywords: EEG, Alzheimer's disease, Wavelet transform, Variance

Nowadays, based on a broad survey of the relevant literature, the diagnostic accuracy of electroencephalograms (EEG) in AD is currently around $80 \%$. Therefore, the most critical issues targeted by EEG studies on AD involve improving the accuracy of the differential diagnosis of AD. In this regard, Musha et al. indicated the possibility that even mild cognitive impairment (MCI) could be detected with high sensitivity by evaluating the variance of power of the EEG. Therefore, it is considered that the variance of power of the EEG is an important index of neuronal abnormality in $\mathrm{AD}$ patients.

In this paper, we propose a new method for diagnosing Alzheimer's disease (AD) on the basis of EEG. The method, which is termed "Power Variance Function (PVF) method", indicates the variance of the power at each frequency. By using the proposed method, the power of EEG at each frequency $P_{i}(f, t)$ was calculated by Continuous Wavelet Transform (CWT).

$$
P_{i}(f, t)=\left\|C W T\left[\frac{x_{i}(t)}{\sqrt{<x_{i}^{2}(t)>}}\right]\right\|^{2}, \ldots \ldots \ldots \ldots .
$$

where $C W T[x(t)]$ shows the CWT of $x(t), x(t)$ is the target time series, $<>$ shows the average of the series. In this paper, we use the Gabor wavelet. And the corresponding variances were defined as PVF shown below.

$$
\begin{aligned}
P V F(f) & =<\left(P_{i}(f, t)-<P_{i}(f, t)>\right)^{2}> \\
& =<P_{i}^{2}(f, t)>-<P_{i}(f, t)>^{2} .
\end{aligned}
$$

Fig. 1 shows an example of PVF calculated from EEG of a AD patients on F3.

After the PVF histogram of 55 healthy people was approximated as a Generalized Extreme Value (GEV) distribution, we evaluated the PVF of 22 patients with $\mathrm{AD}$ and 25 patients with mild cognitive impairment (MCI). As a result, the values for all $\mathrm{AD}$ and MCI subjects were abnormal. In particular, the PVF in the $\theta$ band for MCI patients was abnormally high, and the PVF in the $\alpha$ band for AD patients was low.
In the future, we will apply our method in the development of a sensitive algorithm for the diagnosis of MCI.

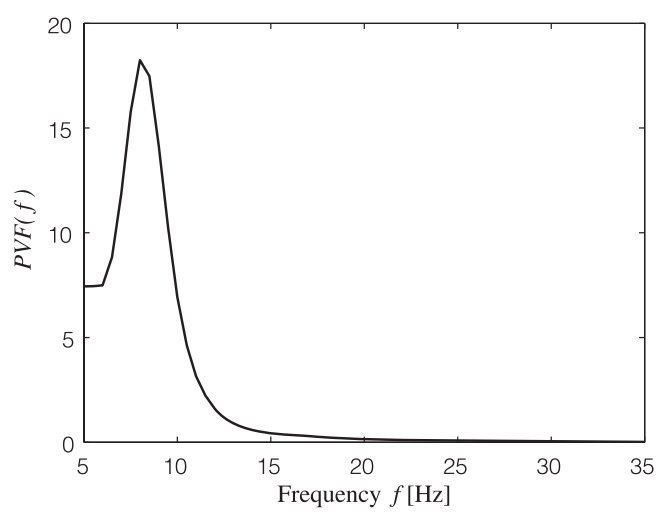

Fig. 1. PVF of an AD patient calculated on F3

(a) Ratio of subjects with hypoactive PVF in each group Frequency $\mid$ Healthy $(\mathrm{n}=55) \quad$ MCI $(\mathrm{n}=25) \quad$ AD $(\mathrm{n}=22)$

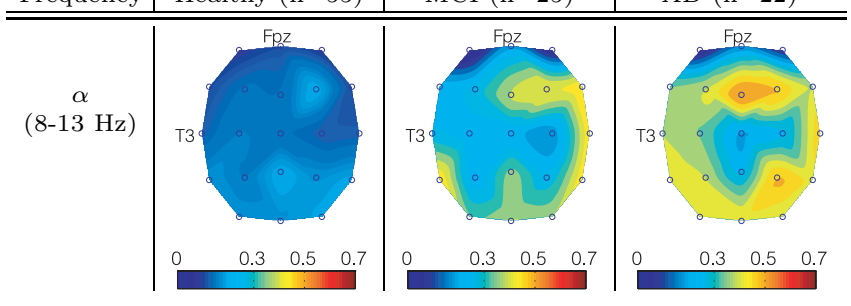

(b) Ratio of subjects with hyperactive PVF in each grous \begin{tabular}{l|l|l|l} 
Frequency & Healthy $(\mathrm{n}=55)$ & MCI $(\mathrm{n}=25)$ & $\mathrm{AD}(\mathrm{n}=22)$ \\
\hline \hline
\end{tabular}

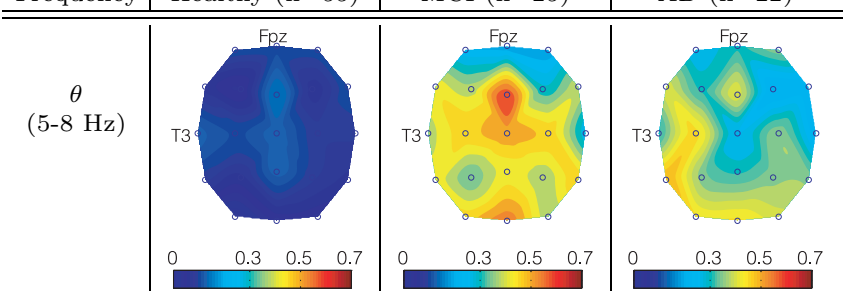

Fig. 2. Ratio of subjects with abnormality in each groups 


\title{
脳波解析によるアルツハイマー病の特性に関する研究
}

\author{
非会員 上田 泰士* 非会員 武者 利光** \\ 正員八木透*,***
}

Research on the Characteristics of Alzheimer's Disease Using EEG

Taishi Ueda*, Non-member, Toshimitsu Musha**, Non-member, Tohru Yagi*,***, Member

In this paper, we proposed a new method for diagnosing Alzheimer's disease (AD) on the basis of electroencephalograms (EEG). The method, which is termed Power Variance Function (PVF) method, indicates the variance of the power at each frequency. By using the proposed method, the power of EEG at each frequency was calculated using Wavelet transform, and the corresponding variances were defined as PVF. After the PVF histogram of 55 healthy people was approximated as a Generalized Extreme Value (GEV) distribution, we evaluated the PVF of 22 patients with $\mathrm{AD}$ and 25 patients with mild cognitive impairment (MCI). As a result, the values for all $\mathrm{AD}$ and MCI subjects were abnormal. In particular, the PVF in the $\theta$ band for MCI patients was abnormally high, and the PVF in the $\alpha$ band for AD patients was low.

キーワード：脳波, アルッハイマー病, ウェーブレット変換, 分散

Keywords: EEG, Alzheimer's disease, Wavelet transform, Variance

\section{1. 緒 言}

認知症は，高齢者本人にとってだけでなく社会的にも大 きな問題となっている。認知症の原因として最も多いと考 えられているのが, アルッハイマー病 (AD: Alzheimer's disease）である。 $\mathrm{AD}$ は進行性の認知症であり, 早期発見 によりその進行を遅らせることが可能であるため, ADの 早期発見と適切な治療が重大な課題となっている ${ }^{(1)}$ 。現在, $\mathrm{AD}$ 診断には SPECT, PET が多く利用されているが，こ れらには被曝や高額な費用といった問題がある。また，非 侵襲で脳血流変化を計測できる NIRSも注目されている

\footnotetext{
$*$ 東京工業大学 大学院情報理工学研究科

₹ 152-8552 東京都目黒区大岡山 2-12-1-W8-20

Graduate School of Information Science and Engineering, Tokyo Institute of Technology

2-12-1-W8-20, O-okayama, Meguro-ku, Tokyo 152-8552

$* *$ (株) 脳機能研究所

† 226-8510 横浜市緑区長津田町 4259-3 東工大横浜ベンチャー プラザ W301

Brain Functions Laboratory, Inc.

Tokyo Tech Yokohama Venture Plaza W301, 4259-3, Nagatsuta-cho, Midori-ku, Yokohama 226-8510

*** 独立行政法人理化学研究所 名古屋支所

７ 463-0003 愛知県名古屋市守山区下志段味穴ヶ洞 2271-130

The Institute of Physical and Chemical Research (RIKEN) Nagoya Branch

2271-130, Anagahora, Shimoshidami, Moriyama-ku, Nagoya 463-0003
}

が，その測定原理から精度に限界があり，NIRS で得られ る情報は脳の神経活動そのものではないため, 同手法の有 効性については未だ多くの議論がある(2)。これらに対し脳 波 (EEG: electroencephalogram) は非侵襲かつ低価格で 診断が可能であり，神経活動を直接反映した情報であるた め, 脳波を利用した診断方法の研究開発が各所で進められて いる。

最も多く研究が行われているのは脳波のスペクトル解析 に基づいた診断方法である(3)。しかし，スペクトル解析に 基づいた診断方法では， $\mathrm{AD}$ と健常者の判別率は $80 \%$ 程度 である。特に軽度 AD である Mild Cognitive Impairments （MCI）の判別が困難であるため，その精度の向上が課題 となっている(1)。他に脳波の dimensional complexity に 注目した研究 ${ }^{(4)} や$, 電極間のコヒーレンスに注目した研

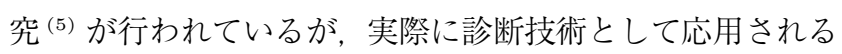
には至っていない。近年, 脳波電位の二乗值のゆらぎに注 目することで, MCI さえも高感度に検出できる可能性が示

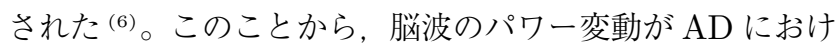
るニューロン異常の重要な指標となると考えられるが, 脳 波のパワー变動と周波数との関係は未だ解析されていない。

そこで本研究では, 脳波電位のパワー变動を周波数成分 毎に計算し，これを $\mathrm{AD}$ の早期発見技術へ応用することを 目標として, 連続ウェーブレット変換を利用したパワー変 動特性の評価方法を提案する。そして, 健常者, MCI 患者, $\mathrm{AD}$ 患者を提案手法で解析し, 提案手法の有用性を示す。 


\section{2. 脳波データ}

脳機能研究所と国立精神神経センター武蔵病院の共同 研究 (7) で収録した脳波データベースから, 健常者 55 名 (57〜89 歳, MMSE: Mini-Mental Status Exam が 24〜 $30)$, MCI 患者 25 名 $(49 \sim 86$ 歳, MMSE は 24〜30), AD 患者 22 名 (60〜88 歳, MMSE は 4 23) を抽出して解析 を実施した。なお，MCI患者は脳波測定後 12〜18ヶ月以内 に possible $\mathrm{AD}(\mathrm{AD}$ の可能性がある)，または probable $\mathrm{AD}(\mathrm{AD}$ の可能性が高い) と診断された患者で, 本研究の 計算で用いた脳波は初回の計測で得られたものである。

脳波計は三栄電気製 Biotop を用い, 電極は国際 $10-$ 20 法に従い 21 箇所 (Fp1, Fp2, Fpz, F3, F4, Fz, F7, F8, C3, C4, Cz, T3, T4, T5, T6, P3, P4, Pz, 01, $02,0 \mathrm{z})$ に取り付けた。アース電極は $\mathrm{Cz}$ と $\mathrm{Fz}$ の中間に取 り付け,リファレンス処理には AV 法 (Average potential reference）を用いた。被験者は閉眼安静状態とし，サンプ リング周波数 $200[\mathrm{~Hz}]$ で 5 分間測定した。測定環境は一般 的な病院の個室で，シールドルームは用いていない。

\section{3. 方 法}

本研究では, 以下の手順によって健常者, $\mathrm{MCI}$ 患者, $\mathrm{AD}$ 患者の, 脳波の周波数毎のパワー変動特性を解析する。

（1）脳波の周波数毎のパワー変動をウェーブレット変 換により求める

（2）周波数毎のパワー変動から周波数毎のパワー変動 の分散 (PVF: Power Variance Function) を求める

（3）健常者のPVF の分布から，PVF の異常判定基準 を算出し，それを元に被験者を評価する

$\langle 3 \cdot 1\rangle$ 各周波数成分のパワー変動特性の計算 提案 手法では脳波の各周波数成分の変動特性を, 連続ウェーブ レット変換 (CWT: Continuous Wavelet Transform)に よって計算する。CWT は次式で定義される ${ }^{(8)}$ 。

$$
\begin{aligned}
& C W T[x(t)](a, t) \\
& \quad=\frac{1}{\sqrt{a}} \int_{-\infty}^{\infty} x(\tau) \overline{\psi\left(\frac{t-\tau}{a}\right)} d \tau .
\end{aligned}
$$

ここで, $C W T[x(t)]$ は $x(t)$ の連続ウェーブレット変換を 表す。 $x(t)$ は解析信号, $\psi(t)$ はマザーウェーブレット, $a$ はスケールパラメータ, $\overline{\psi(t)}$ は $\psi(t)$ の複素共役を示す。本 研究では, 信号の局所的な周波数成分の検出能力に優れて いる Gabor のマザーウェーブレット $((2)$ 式) を用いてい る(9)。

$$
\psi(t)=\frac{1}{2 \sqrt{\pi} \sigma} e^{-\frac{t^{2}}{\sigma^{2}}} e^{-j 2 \pi f_{0} t} .
$$

$\sigma$ はウェーブレットのガウス空の幅を決めるパラメータ, $f_{0}$ は卓越周波数である。今回は，予備実験の結果を踏まえて $\sigma=8, f_{0}=1$ とした。

$C W T[x(t)]$ の絶対值は $x(t)$ の周波数 $f=f_{0} / a$ のパワー 変動特性を表すことが知られている ${ }^{(10)}$ 。電極 $i$ で測定さ
れた脳波電位を $x_{i}(t)$ とすると, 式 $(1)$ で $x(t)=x_{i}(t)$ と し, その絶対值を求めることで測定脳波の各周波数成分の パワー変動特性を得ることが可能である。しかし, 脳波電 位のレベルは個々の被験者によって異なる。この影響を取り 除くために, $x_{i}(t)$ の平均振幅で $x_{i}(t)$ を除した信号に対し て CWT を計算し, CWT の絶対值の二乗を規格化パワー 変動 $P_{i}(f, t)$ と呼ぶことにする。

$$
P_{i}(f, t)=\left\|C W T\left[\frac{x_{i}(t)}{\sqrt{<x_{i}^{2}(t)>}}\right]\right\|^{2} \ldots \ldots \ldots .
$$

ここでく>は時間平均を表す。

例として Fig. 1 に，ある健常者の脳波について，F3での 規格化パワー変動 $P_{F 3}(f, t)$ を実際に計算した結果の一部 を示す。 $10 \mathrm{~Hz}$ 付近のパワーが特に大きい值をとっている ことが分かる。

〈3.2〉 PVF: Power Variance Function 脳波の パワー変動の活発さを評価するために，(3) 式で与えられ た $P_{i}(f, t)$ の分散 $\sigma_{i}^{2}(f)$ を計算する。

$$
\begin{aligned}
\sigma_{i}^{2}(f) & =<\left(P_{i}(f, t)-<P_{i}(f, t)>\right)^{2}> \\
& =<P_{i}^{2}(f, t)>-<P_{i}(f, t)>^{2}
\end{aligned}
$$

$\sigma_{i}^{2}(f)$ は $(4)$ 式で示されるように周波数 $f$ を変数とする 関数になる。この $P_{i}(f, t)$ の分散 $\sigma_{i}^{2}(f)$ を, PVF (Power Variance Function) と定義する。つまり PVF は電極位置 $i$ で記録された脳波において周波数 $f$ である成分のパワー 変動がどれくらい活発であるかを表す指標となる。

〈3・3〉 PVF の異常判定基準の算出 実際に健常者 55 人の電極位置 F3 で計測された脳波から計算した PVF を Fig. 2 に示す。それぞれの実線は, 各被験者の PVF を 示している。この図に示されるように，特定の電極および

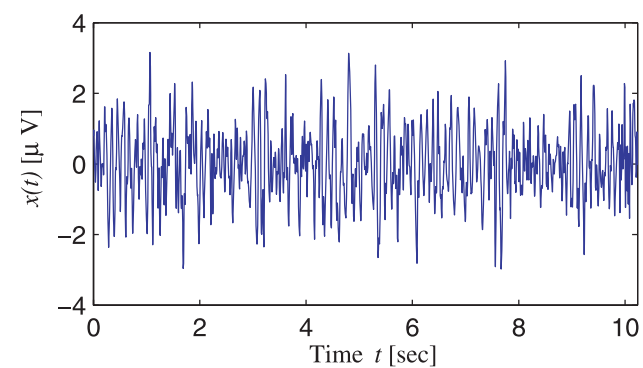

(a) Original signal

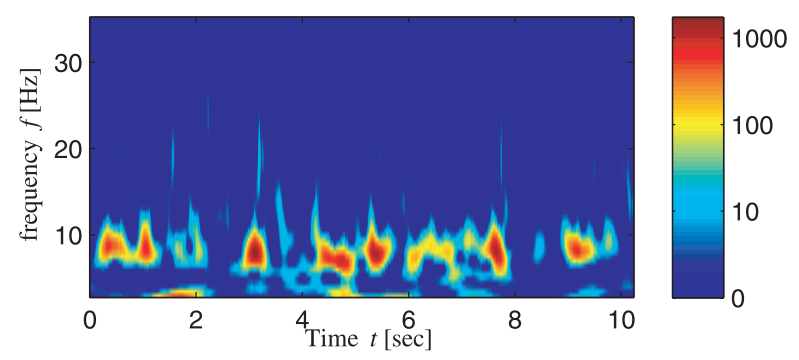

(b) Time series of normalized power

Fig. 1. Time series of normalized power of a healthy subject on F3 
周波数における PVF は被験者ごとに異なる。しかし 8 $10[\mathrm{~Hz}]$ 付近のピークは, 健常者の脳波のパワー変動が特に 8〜10 [Hz] 付近で活発であることを示している。

そこで，健常者が各周波数でどのような PVFをとりや すいかを把握するために，縦軸を PVF，横軸を健常者の人 数としたヒストグラムを各電極の各周波数について作成し た。ヒストグラムの階級数は Sturges の方法 ${ }^{(11)}$ に基づい て 6 とした。Fig. 3(a) の棒グラフは電極位置 F3, 周波数 $8.0[\mathrm{~Hz}]$ における健常者 55 人分のヒストグラムである。こ の図が示すように，健常者の PVF は正規分布をなさず，ゼ 口付近へ歪んだ分布をしている。

次に，任意のPVF を健常者集団のうちの何\%の被験者 が取り得るかを推定するために，この分布をパラメトリッ ク分布へ近似することを考えた。Fig. 3 (a) のヒストグラム のように，正の值で歪みをもった分布として，対数正規分 布, ガンマ分布, 一般化極值分布 (GEV 分布: Generalized Extreme Value Distribution) が考えられる(12)。今回はこ れら 3 つの分布において最尤推定を試み, 一番良く適合し た GEV 分布を採用することにした。そして健常者の各周

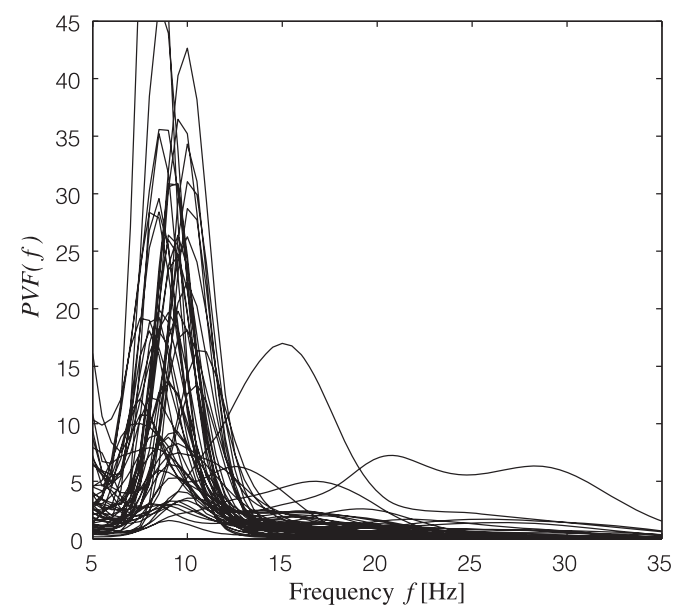

Fig. 2. PVF of 55 healthy subjects on F3
波数毎のPVF が GEV 分布に従うと仮定し，次式に従っ て近似した。

$$
\begin{aligned}
y & =f(x \mid \kappa, \mu, \sigma) \\
& =\frac{1}{\sigma} e^{-\left(1+\kappa \frac{x-\mu}{\sigma}\right)^{-\frac{1}{\kappa}}}\left(1+\kappa \frac{x-\mu}{\sigma}\right)^{\left(-1-\frac{1}{\kappa}\right)} \cdots
\end{aligned}
$$

ここで, $\kappa$ は形状パラメータ, $\mu$ は位置パラメータ, そし て $\sigma$ はスケールパラメータである。GEV 分布はパラメー 夕 $\kappa$ によって， 3 種類に分類される。 $\kappa=0$ の時は夕イ プI，または Gunbel 分布， $\kappa>0$ の時は夕イプII，また は Fréchet 分布， $\kappa<0$ の時はタイプ III，または Weibull 分布と呼ばれる。カイ二乗検定による適合度検定の結果, PVFのほとんどの分布がタイプII (Fréchet 分布) に適合 した。Fig. 3(a)の破線はヒストグラムに適合した GEV 分 布である。Fig. $3(\mathrm{a})$ に示されるように，ある周波数での PVFのヒストグラムを近似した GEV 分布から, PVFの 確率分布の上側 $5 \%$ の領域 $(P V F>h)$ と下側 $5 \%$ の領域 $(P V F<l)$ を推定することができる。これを全周波数につ いて同様に計算し, 横軸に周波数, 縦軸に上下 $5 \%$ となる境 界の PVF をプロットした結果が Fig. $3(\mathrm{~b})$ である。 $E_{l}$ と $E_{h}$ はそれぞれPVF の確率分布の下側 $5 \%$ と上側 $5 \%$ の領 域を表している。被験者の PVFが $E_{l}$ に含まれていれば, 健常者よりも著しくパワー変動が小さい不活発性異常 (hypoacctive abnormality)， $E_{h}$ に含まれていれば，健常者よ りも著しくパワー変動が大きい不安定性異常 (hyperactive abnormality) と呼ぶことにする。

解析では，測定された脳波データに含まれている過大信 号部と無信号部を取り除いた後, 2〜40[Hz] のバンドパス フィルタを施すことで雑音を除去した。その後, 全被験者の 脳波データ長を揃えるために, デー夕長が $2^{15}$ サンプルにな るように余分なデータを除去した。こうして得られたデー 夕に対し，マザーウェーブレットの中心周波数を $0.5[\mathrm{~Hz}]$ 刻みで 5〜 35 [Hz] まで変化させて前述の解析を実施した。

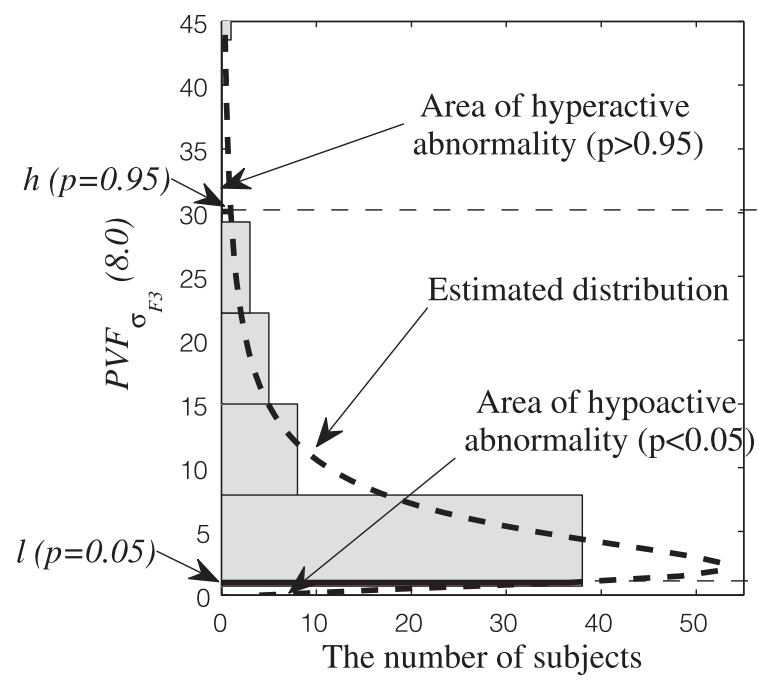

(a) Histogram of PVF and estimated distribution on F3 at $8.5[\mathrm{~Hz}]$

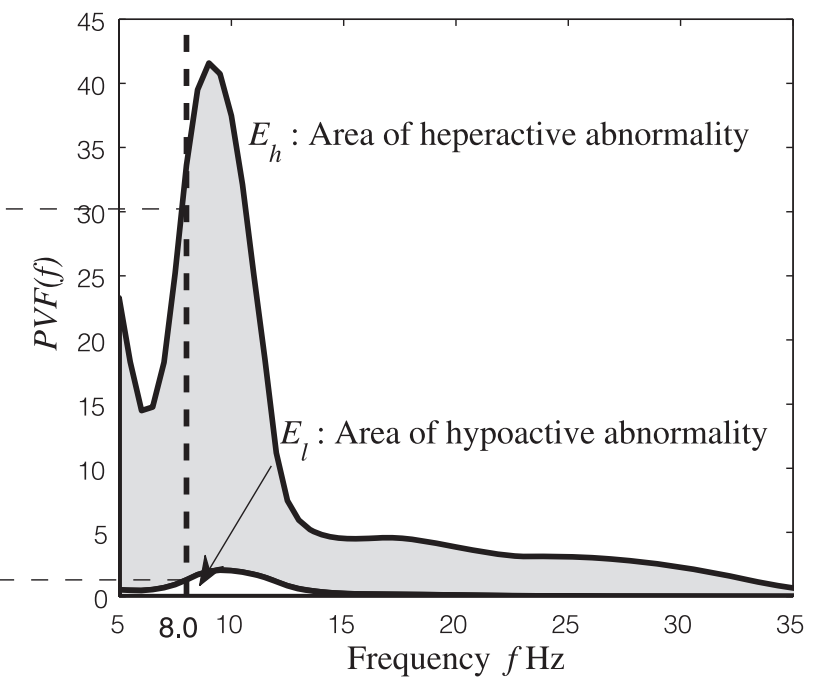

(b) Area of abnormality in F3

Fig. 3. approximation to a general extreme distribution 


\section{4. 結 果}

$\langle 4 \cdot 1\rangle$ 不活発性異常 健常者, MCI 患者, AD 患者 の脳波デー夕の特徵を調べるために, 各グループの中で, 不 活発性異常と分類された人数の割合を $\theta(5 \sim 8 \mathrm{~Hz}), \alpha(8$ $13 \mathrm{~Hz}), \beta(13 \sim 20 \mathrm{~Hz}), \gamma(20 \sim 35 \mathrm{~Hz})$ の带域に分けて計算 した。この分布の割合を電極毎にトポグラフとして示した のが Fig. 4 (a) である。同図の色は異常と判定された人数の 割合を示しており，青が $0 \%$ ，赤が $70 \%$ を表している。図 から明らかなように，異常であった人数の割合は，各電極 位置によって微妙に異なっている。例えば， $\mathrm{AD}$ 患者のグ ループでは前頭葉と側頭葉，後頭葉において $\alpha$ 带域で不活 発性異常をとる人数が多く, 特に Fz と P4においてはおよ そ 6 割の $\mathrm{AD}$ 患者が異常值を示している。 $\beta, \gamma$ 帯域にお いては, 2 3 割程度の患者が側頭葉において不活発性異常 を示している。一方 $\theta$ 帯域では不活発性異常に分類される 患者は少なく，1 割未満であった。

MCI 患者のグループでも同様に前頭葉と側頭葉，後頭葉 に扔いて $\alpha$ 帯域で不活発性異常となる人数が多いが， $\mathrm{AD}$ 患者よりは少なかった。しかし $\beta, \gamma$ 帯域に扔いては, $\mathrm{AD}$ 患者よりも異常值をとる割合が高く，特に $\beta$ 帯域での F4, $\gamma$ 带域での T5 では拉よそ 4 割の MCI 患者が不活発異常 となっている。左側頭部の $\mathrm{T} 5, \mathrm{Cz}$ の $\beta$ 带域で 3 割の $\mathrm{MCI}$ 被験者が不活発性異常となった。 $\theta$ 帯域では $\mathrm{AD}$ 患者と同 様に不活発性異常と分類された患者は 1 割未満であった。

健常者のグループでは，全チャンネルの全帯域において 異常值をとった被験者の割合は 1 割未満であった。

$\langle\mathbf{4} \cdot \mathbf{2}\rangle$ 不安定性異常 次に, Fig. 4 (a) と同様にして 不安定性異常と分類された被験者の割合を Fig. 4 (b) に示 した。 $\mathrm{AD}$ 患者のグループでは，前頭葉と側頭葉，後頭葉 に扔いて $\theta$ 带域で不安定性異常をとる人数が多い。しかし $\alpha$ 帯域では特徴はみられなかった。 $\beta$ 帯域においては, 右 側頭葉に打いておよそ 4 割の患者が不安定性異常を示した。 MCI 患者のグループでは， $\theta$ 带域に扔いてほほ全ての電極 に扔いて不安定性異常をとって扔り，特に Fzと Ozに扔い ては抄よそ7 割の患者が異常值を示した。一方，それ以外 の周波数帯域では異常值を取る人数は少なかった。健常者 のグループにおいて異常値をとった被験者の割合は， $\alpha$ 带 域の $\mathrm{Fz}, \mathrm{Cz}$ において 2 割程度，それ以外の電極では高々 1 割程度であった。

また，不安定性異常と不活発性異常両方を合わせると，全 ての $\mathrm{AD}$ 被験者が，少なくとも 1 つの電極位置でどちらか の異常性を持つと分類された。

\section{5. 考察}

これまで $\mathrm{AD}$ 患者の脳波のスペクトル解析が数多く行わ れてきた。その中で報告されているのが，特に側頭部にお いて $\alpha, \beta$ 成分が減少し， $\delta, \theta$ 成分が増大寸る徐波化であ る (13) (14)。本研究でも側頭部に押いて $\mathrm{AD} の \alpha$ 成分の不活 発性異常が観察された。このことから, PVF はスペクト
ルの情報も反映していると考えられる。しかし，被験者に よっては必ずしもパワースペクトルと PVF は一致しなかっ た。Fig.5は，PVFとパワースペクトルが著しく異なった 例である。Fig. 5 (a) はPVF であり，5 (b) は，同じデー夕 から計算したパワースペクトル $S(f)$ である。PVFでは, $10 \mathrm{~Hz}$ 付近の值が小さく, $15 \mathrm{~Hz}$ 付近の值が大きいのに対 し，パワースペクトルでは $10 \mathrm{~Hz}$ 付近に大きなピークがあ る。これは, $10 \mathrm{~Hz}$ 付近のパワーが平均的には大きかったた めパワースペクトルでは $10 \mathrm{~Hz}$ 付近にピークが現れた。し かし PVF は時間平均ではなく時間的な変動を数值化する 手法である。Fig. 5 の例ではパワーの時間的な変動は少な かったためにPVFでは小さな值として得られている。また PVFでは，パワースペクトルに表れている $30 \mathrm{~Hz}$ のピーク (矢印) が見られない。この $30 \mathrm{~Hz}$ のピークは計測時に混入 した周期的な雑音であるが，振幅が一定であるためにゼロ になったと考えられる。このようにPVF は雑音に対して も堅牢な指標であると言える。また，本提案手法のように ウェーブレット変換を用いると PVF を滑らかな曲線で表 現できるため, 全体域にわたる連続的な観察が可能となる。

$\langle 3 \cdot 3\rangle$ 節「異常判定基準の算出」では，PVF の分布のほ とんどがタイプII に適合した。Fig. 3 (a)の点線で示した 近似曲線もタイプII である。Fig. 3 (a) から分かるように, タイプII の特徴は，1） 0 付近で裾を持たない，2) 極めて 0 に近い部分に最頻值を持っている，3) 正の方向に長い裙 を持つことである。これはPVF のヒストグラムの特徵と 一致しており，妥当な結果であると言える。

今回 $\mathrm{AD}$ 患者が $\alpha$ 帯域で不活発性異常をとり, MCI 患 者が $\theta$ 带域で不安定性異常をとることが示された。また異 常值をとる電極位置は $\mathrm{MCI}$ 患者と $\mathrm{AD}$ 患者で異なること が分かった。これらの事から， MCI と $\mathrm{AD}$ が異なる異常性 を示しており，健常者との判別には，それぞれ異なる判断 基準を利用する必要があると考えられる。用いる脳波の周 波数带域, 電極位置, 注目寸る異常性 (不活発か不安定か) を適切に選択することで，MCI 患者も $\mathrm{AD}$ 発病前の段階 で判別することが可能になると考えられる。

全ての $\mathrm{AD}$ 患者が異常性を示したが，健常者であっても $\mathrm{Fz}, \mathrm{Cz}$ に扔いては $\alpha$ 帯域に扔いて 2 割程度が異常性を示 すことがあった。この原因としては， $\alpha$ 波の個人差が大き く, そのヒストグラムが多峰となり, GEV 分布の近似曲線 の適合が十分ではなかったことが考えられる。これについ ては今後 $\mathrm{AD}$ の判別アルゴリズムを考える上で十分に考慮 する必要がある。特に, 今回はPVFの分布が一般化極值 分布であると仮定して解析を行ったが，今後高精度な判別 を行うためには, PVF と一般化極值分布の理論的な関係の 調査や，他の分布を併用できるかを調査する必要があるだ ろう。

\section{6. 結論と今後の展望}

本論文では脳波の各周波数成分のパワー変動を評価する 手法を提案し，脳波データから異常を判定することを試み 


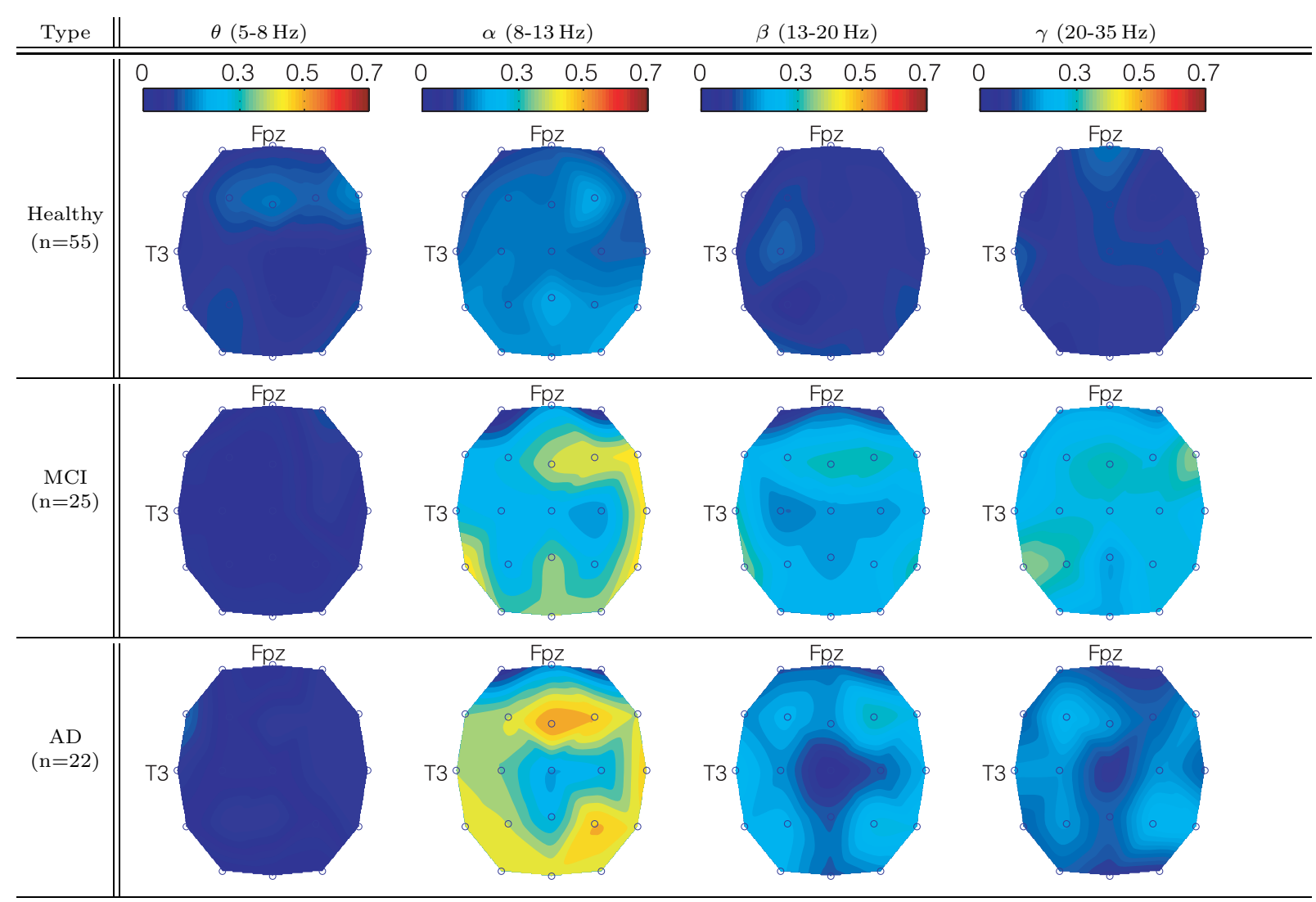

(a) Ratio of subjects with hypoactive PVF to normal subjects

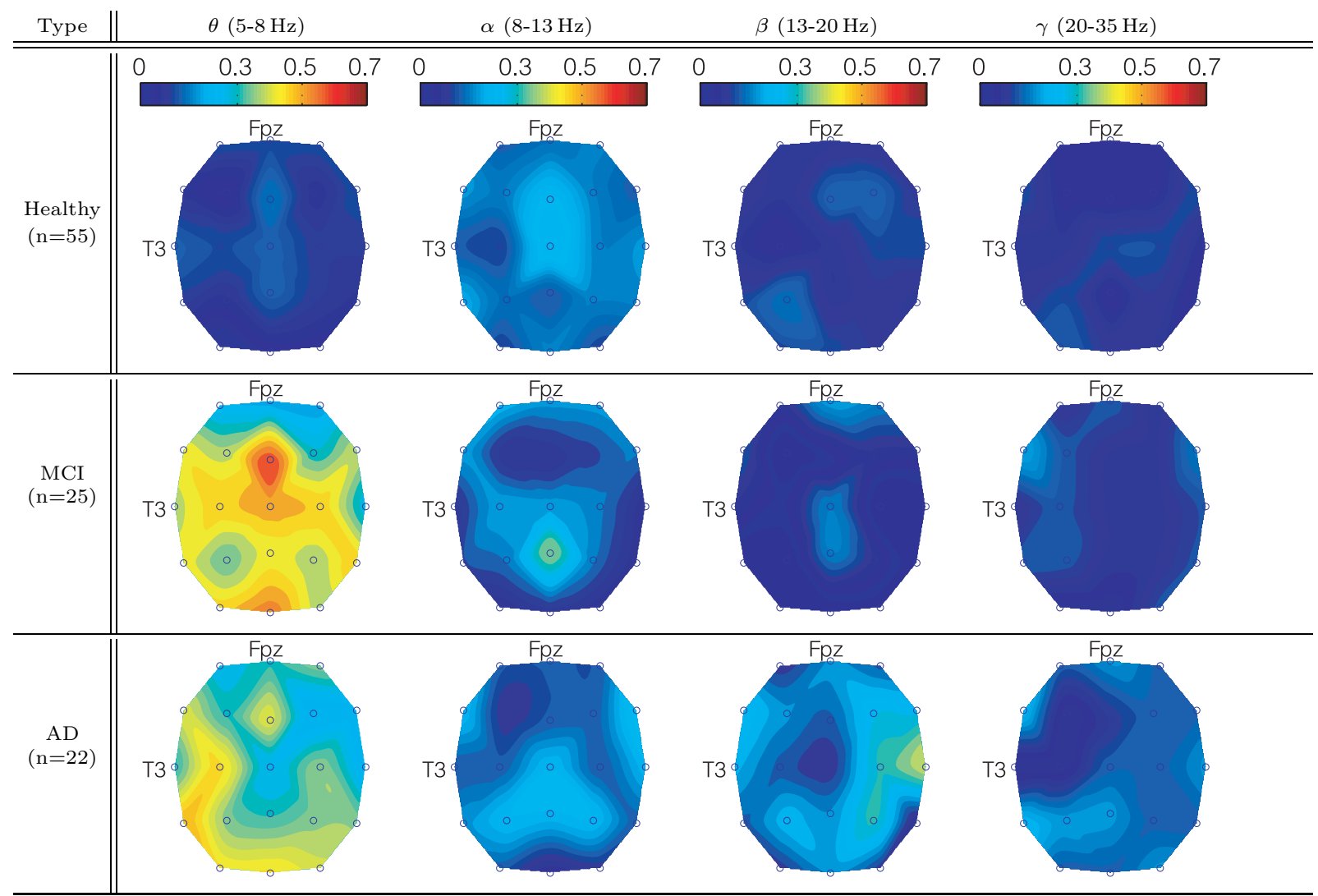

(b) Ratio of subjects with hyperactive PVF to normal subjects

Fig. 4. Ratio of subjects with hyperactive abnormality to normal subjects 


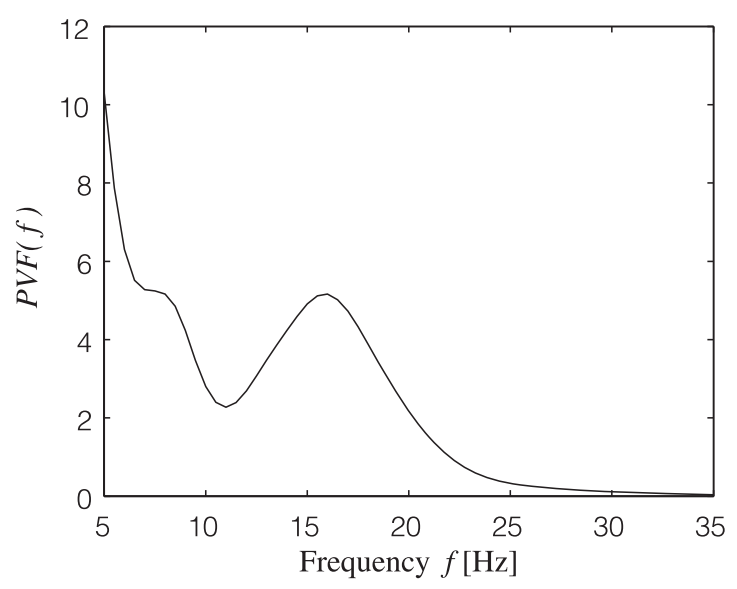

(a) PVF of the data on F3

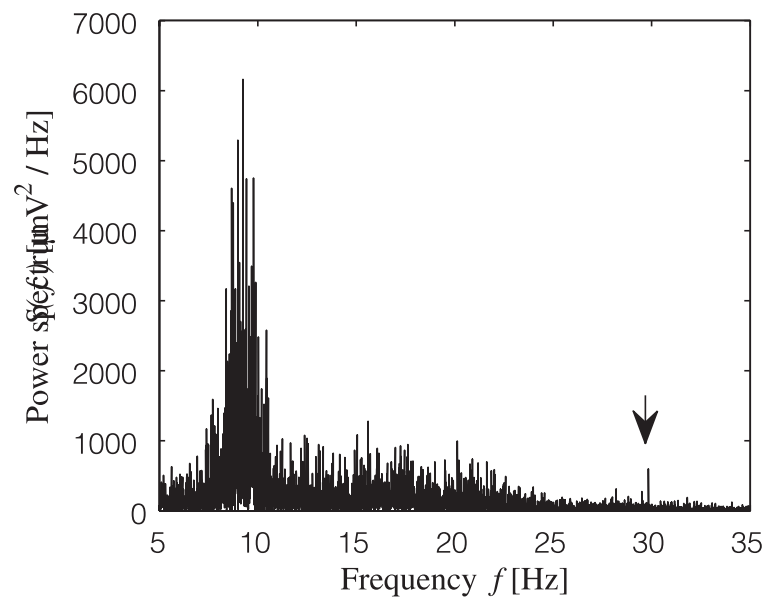

(b) Power spectrum of the data

Fig. 5. The example of PVF

た。健常者, MCI 患者, $\mathrm{AD}$ 患者の脳波を提案手法で評価 したところ， $\mathrm{AD}$ 患者は $\alpha$ 帯域で不活発性異常を，MCI 患 者は $\theta$ 帯域で不安定性異常を示し，MCIでも脳波によって 高感度に判別できる可能性が示された。今後，注目すべき 電極位置や，周波数帯域，不活発性異常と不安定性異常ど ちらの異常性であるのかを考慮し，MCI も高感度に判別で きる適切な判別アルゴリズムへ発展させる予定である。 (平成 21 年 11 月 2 日受付, 平成 22 年 5 月 20 日再受付)

\section{文献}

（1）松田博史·朝田 隆：「痴呆の画像診断一診て見て学ぶ」, 永井書店 (2004)

(2) H. Eda: "Near infrared spectroscopic measurement of brain activation and its limitations", Technical report of IEICE. HIP, Vol.106, No.328, pp.63-66 (2006)

(3) J. Jeong: "EEG dynamics in patients with Alzheimer's disease", Clinical Neurophysiology, Vol.115, No.7, pp.1490-1505 (2004)

(4) C. Besthorn, H. Sattel, C. Geiger-Kabisch, R. Zerfass, and H. Förstl: "Parameters of EEG dimensional complexity in Alzheimer's disease", Electroencephalography and Clinical Neurophysiology, Vol.95, No.2, pp.84-89 (1995)

(5) T. Locatelli, M. Cursi, D. Liberati, M. Franceschi, and G. Comi: "EEG coherence in Alzheimer's disease". Electroencephalography and clinical neurophysiology, Vol.106, No.3, pp.229-237 (1998)

(6) H. Matsuzaki and T. Musha: "A new tool for differential diagnosis of alzheimer's disease, l-dimension", Clinical Neurophysiology, Vol.119, No.6, pp.e89-e90 (2008)

( 7 ) T. Musha, T. Asada, F. Yamashita, T. Kinoshita, Z. Chen, H. Matsuda, M. Uno, and W.R. Shankle: "A new EEG method for estimating cortical neuronal impairment that is sensitive to early stage Alzheimer's disease", Clinical Neurophysiology, Vol.113, No.7, pp.1052-1058 (2002)

(8) K. Gurley, T. Kijewski, and A. Kareem: "First-and higherorder correlation detection using wavelet transforms", Journal of Engineering Mechanics, Vol.129, No.2, p.188 (2003)

（9） C.K. Chui ・桜井 明・新井 勉：「ウェーブレット入門」, 東京連 記大学出版局 (1993)

(10) C. Torrence and G.P. Compo: "A practical guide to wavelet l", Bulletin of the American Meteorological Society, Vol.79, No.1, pp.61-78 (1998)

（11）岸根卓郎：「理論応用統計学」, 養賢堂 (1970)

12) S. Kotz and S. Nadarajah: "Extreme value distributions: theory and applications", World Scientific, (2000)

(13) J. Breslau, A. Starr, N. Sicotte, J. Higa, and MS Buchsbaum: "Topographic EEG changes with normal aging and SDAT", Electroencephalography and clinical neurophysiology, Vol.72, No.4, pp.281-289 (1989)

(14) L.J. Streletz, P.F. Reyes, M. Zalewska, L. Katz, and R.G. Fariello: "Computer analysis of EEG activity in dementia of the Alzheimer's type and Huntington's disease", Neurobiology of Aging, Vol.11, No.1, pp.15-20 (1990)

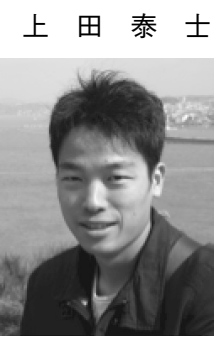

（非会員） 1984 年 8 月 4 日生。 2008 年 3 月東 京工業大学工学部機械宇宙学科卒業。同年 4 月, 同大学大学院情報理工学研究科情報環境学専攻修 士課程入学。現在，脳波を用いた認知症の診断方 法に関する研究に従事。

武 者 利 光 (非会員) 1931 年 6 月生。1954 年東京大学理学

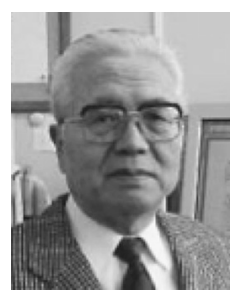
部物理学科卒業。1954 年日本電信電話公社電気通 信研究所研究員。1964 年マサチュ-セッツ工科大学 (米国) 研究員（フルブライト交換研究員）。1965 年王立工科大学 (スウェーデン) 研究員。1966 年 RCA 東京研究所研究員, 及び東京工業大学工学部 総合理工学研究科教授, パリ大学客員教授。1992 年東京理科大学教授。1994 年 (株) 脳機能研究 所および (株) ゆらぎ研究所を設立，代表取締役に就任。1994 年 11 月神奈川工業技術大賞受賞 (脳機能解析技術の開発)。1997 年帝京平 成大学教授。 2000 年（財）機械振興協会より中堅·中小企業新機械 開発賞受賞 (感性解析法の開発)。2001 年 4 月～2003 年 3 月理化学 研究所脳研究センター非常勤研究員, 現在に至る。「1/fゆらぎ」と生 体の快適性の研究, 脳波による感情計測や認知症の判別技術の研究に 従事。

八木

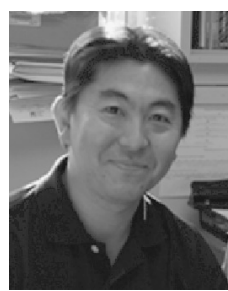

透（正員） 1967 年 3 月 30 日生。1996 年名古屋大 学大学院博士課程修了。同年理化学研究所基礎科 学特別研究員。1998 年名古屋大学助手。2001 年 ニデック人工視覚研究所所長。2004 年理化学研 究所研究員。2005 年東京工業大学准教授, 現在 に至る。脳や視覚を中心とした医用生体工学, 生 体情報工学, ロボット・システム工学に関する基 礎・応用研究に従事。工学博士。 